\title{
FAITH, DEATH, AND THE INTERNET IN NORWAY \\ AND SWEDEN
}

\section{ANDERS GUSTAVSSON}

The all-inclusive issue in studies of memorial websites on the internet concerns how mourners express their emotions and concepts of beliefregarding a deceased person's afterlife. The living believe that their ultimate contact with the deceased will occur after their own death. In Sweden, this also applies to deceased pets. Memorial websites to the deceased generally contain far more traditional Christian concepts in Norway than in Sweden. In Sweden one observes more of a diffuse, general religiosity that can remind one of New Age modes of thought in which individualism.

Keywords: angels, faith, heaven, pets, memorial websites, suicide
Eno glavnih vprašanj pri raziskavah spominskih spletnih mest se nanaša na to, kako žalujoči izražajo čustva in katera prepričanja o posmrtnem življenju pokojne osebe prevladujejo. Živi verjamejo, da se bodo po lastni smrti srečali s pokojnikom in z njim večno živeli. Na Švedskem velja to tudi za pokojne hišne ljubljenčke. To labko razberemo tudi na spominskih spletnih mestih, kjer je na Norveškem veliko več tradicionalnih krščanskih konceptov kakor na Švedskem. $\mathrm{Na}$ Švedskem opazimo bolj razpršeno, splošno religioznost, ki lahko spominja na novodobne načine mišljenja, v katerih je $v$ ospredju individualizem.

Ključne besede: angeli, vera, nebesa, hišni ljubljenčki, spominska spletna mesta, samomor

\section{INTRODUCTION}

Written messages on the internet relating to persons that have died in recent years comprise a new medium for expressing concepts of faith (Krawczyk-Wasilewska et al., 2012). This new medium affords undreamt-of and hitherto quite unexploited opportunities for conducting cultural research by allowing access to the emotions, beliefs, and experiences of present-day people (Margry et al., 2011). Such memorial websites have increased very noticeably in the past few years. Messages about one and the same deceased person can continue over several years in connection with, for example, birthdays, name days, and anniversaries of the death. Both relatives and friends can express themselves about and to the deceased person. This research deals with fifty-six memorial websites that have become available in Norway and Sweden, with the most extensive material being found in Sweden. ${ }^{1}$ These memorial websites were set up by people that had recently suffered extreme grief in their immediate relationships. This study examines websites that are open to the public. Emphasis is placed on analysis of the content of the messages that stress a perspective of faith, and the research is by no means quantitative.

1 My sources are recorded in Gustavsson 2011: 161, 180, 196, April 1, 2011. 
The research questions are the following: How are concepts of an existence after death expressed? What is the deceased's status considered to be on the other side? Is any form of dialogue possible with her or him? Can the surviving persons at some future time after their own deaths be reunited with their dead loved ones? How do the survivors use the verbs believe and know when they speak of supernatural matters?

\section{THE EXISTENCE OF THE DECEASED IN HEAVEN}

The concept that a deceased person is somewhere in heaven is common. There he or she can meet with others that have died. A new fellowship is assumed to have occurred after death. Existence in heaven is considered to be very similar to that on Earth. The life that is conceived of in the conceptual world is a very concrete and pleasant one. One never encounters negative concepts of existence in heaven. This is reminiscent of the neo-religious ideas of "the recaptured paradise," which the Norwegian folklorist Bente Gullveig Alver has analyzed (Alver, 1999b; Kraft, 2011).

Deceased persons are believed to be able to continue practicing their activities in heaven. This can relate to motocross, such as Marcus loved until his death in 2008 at age twenty-three. A message about him said: "We hope you're happy there among the angels and that you do a lot of motocross racing." A photograph of the young man on his bike is included.

Doubt and clear denial of any form of existence after death are very rare in the messages. Some of them do not mention belief in any form of existence after death.

A person's concept of an invisible existence can change when a sudden death occurs in his or her own immediate circle. It seems impossible to believe that everything has quite simply stopped. This is especially true with regard to deaths among children and young people. Such nascent and completely new ideas occur in the messages expressed by the mother of Max and Saga, who were murdered in 2008:

I have never been a believer. Never believed in God and been fairly skeptical to concepts of a life after death. But after this ... I still am not a believer. But I want to believe that something happens after death. I want to believe that Max and Saga are well and happy, and that they are with each other... I want to believe this, and then I do believe it. I do not believe that any God exists. But I must believe that my angels are really angels and are happy now.

In other words, belief in an existence after death and in angels can exist even if one has no faith in God. This is not a traditional Christian religion that has become tangible in a postmodern, secular Sweden. Instead, it is a conceptual world that the afflicted persons themselves can create to find some form of consolation. An individualism of this kind, which is freed from traditional religiosity, is a characteristic of neo-religious trends (Gilhus, Mikaelsson, 2005). 


\section{OPPORTUNITIES FOR CONTACT WITH THE DECEASED}

It is often thought that the deceased can be contacted by the living and that the living can even communicate their messages to the deceased on a computer. A mother wrote to her deceased son: "I think of you all the time and wish that I could telephone you and hear your voice. Now I'll send this e-mail up to heaven instead and hope that it reaches you. If you want anything, my dearest boy, I'll be sitting here at my computer for a while every day."

As can be seen in this message, the deceased are also thought to be able to contact the living. There is a notion that the deceased also have a computer. The technical possibilities of this life are transferable to the existence on the far side of death.

When the deceased are in heaven, they are often believed to participate in events on Earth. They both watch over and protect their friends and relatives. Camilla wrote to her "pal" Andreas, who died in 2008 at age twenty-three: "I know that when I look up toward heaven I am certain that you are sitting there and looking down and keeping all your friends out of trouble, because your friends have always been important for you." The words know and certain instead of believe suggests that Camilla is very convinced about the truth of what she writes.

The concept of a reunion with the deceased sometime in the future often appears in the messages. A new existence and fellowship can begin that will never end. Finiteness is replaced by the everlasting, and joy is restored supremely. This is something to look forward to as a consolation in one's state of grief. After Viktor was murdered in 2007, at age forty, his girlfriend wrote: "When we meet again we will get married. Love you, try to take it easy up there, and some fine day we'll be dancing our salsa again."

Such belief in being reunited is, however, far more diffuse in a great many other cases. It is not dependent on any particular religious basis. A mother wrote about her son, who had died at age twenty-five: "My only hope is that I will see him again sometime." The expression of faith can be far more substantial in those other cases, which refer to God and angels.

Muslim writers, who are actually not so very numerous in the material studied, speak of the paradise named in the Koran. The writers are completely convinced about being reunited there. This is indicated by the use of the verb know instead of think. The wife of Samir, who died at age twenty-six in 2007, wrote: "I know that we will meet again and continue our lives together in paradise, I know that you are waiting for me. . . My life now is just one long transit stage until we meet again."

Explicit concepts of hell or of punishment after death in the messages are written only about those that have murdered a loved one or some other person close to the writer. Thoughts of revenge after the death are then expressed clearly, if not very often, in the messages. 


\section{THE DECEASED MEETING WITH ANGELS AND OTHER DIVINE BEINGS}

Belief in angels occurs very often in the messages. In order to enter their world, the deceased must climb an unendingly long stairway that is depicted in some of the messages.

Meeting with angels is described in a clearly positive context for the deceased. After Richard died in 2008 at age twenty-seven, his cousin Laura wrote: "Your last journey to heaven has taken place and a lot of angels are carrying you there on their wings." A deceased person can also speak in poetic form about how happy he or she is among the angels. This can help comfort mourners. When Marcus suddenly died in 2002 at age twenty, his mother cited poems in which her son spoke to her from heaven. One poem begins:

Mummy dear, I see you from my new home, / This home where all the angels dwell. I I have so many friends, angels who are young and old. I Here no age matters, I Only a great love for one another, / Mummy dear, where angels dwell it is just so beautiful, I Mummy, I want you to know that I am so happy here.

Because it is so good to be "where angels dwell,"Marcus' mother believes that her son "will have a wonderful birthday party up there with the angels. I can see how you smile and laugh on your special day."This was written on Marcus' twenty-fifth birthday, in 2007, five years after his death.

When angels are the beings most discussed as having a supernatural or divine character, this is in keeping with New Age concepts (Alver, 1999a; Kraft, 2011). God is then more distant.

In the memorial website messages, however, there are examples of God and Jesus also being mentioned in addition to angels. This is then seen as being a positive element for the deceased. When four-month-old Nicolai died, his family wrote: "God had other plans for you. He wanted you near him and you left us behind with our despair and loss." Another expression is that the deceased was a gift or a loan from God. In poems in which the deceased speaks, he or she often tells of the existence on the far side of death. This is usually an optimistic description of how happy they are. Several of these messages mention not only angels but also God and Jesus.

God and Jesus are mentioned far more often in Norwegian than in Swedish messages. This is especially noticeable in messages written by teenagers. When Trond was killed in a traffic accident at age fifteen, three girls from his school class wrote: "God loves to pick flowers, and now he has picked the finest one - that's you, Trond." Numerous Norwegian messages state that a person's life is a loan from God, which He can reclaim sooner or later. In crisis situations it may therefore be easier to mention and approach God in Norway than it would appear to be in Sweden. The secularization seems to have been more prevalent in Sweden than in Norway.

Muslim writers refer to both Allah's protection and to angels, which are named in the Koran (http://www.ne.se, Islam). When five-month-old Mohammed Osmanaj died in 2004, his parents wrote: “We seek Allah's protection from shaitan's evil mind." In a poem, the dead child is speaking to his parents: "Last night I imagined an angel came / And took me by the hand / We flew together far away / Over sea and land." 


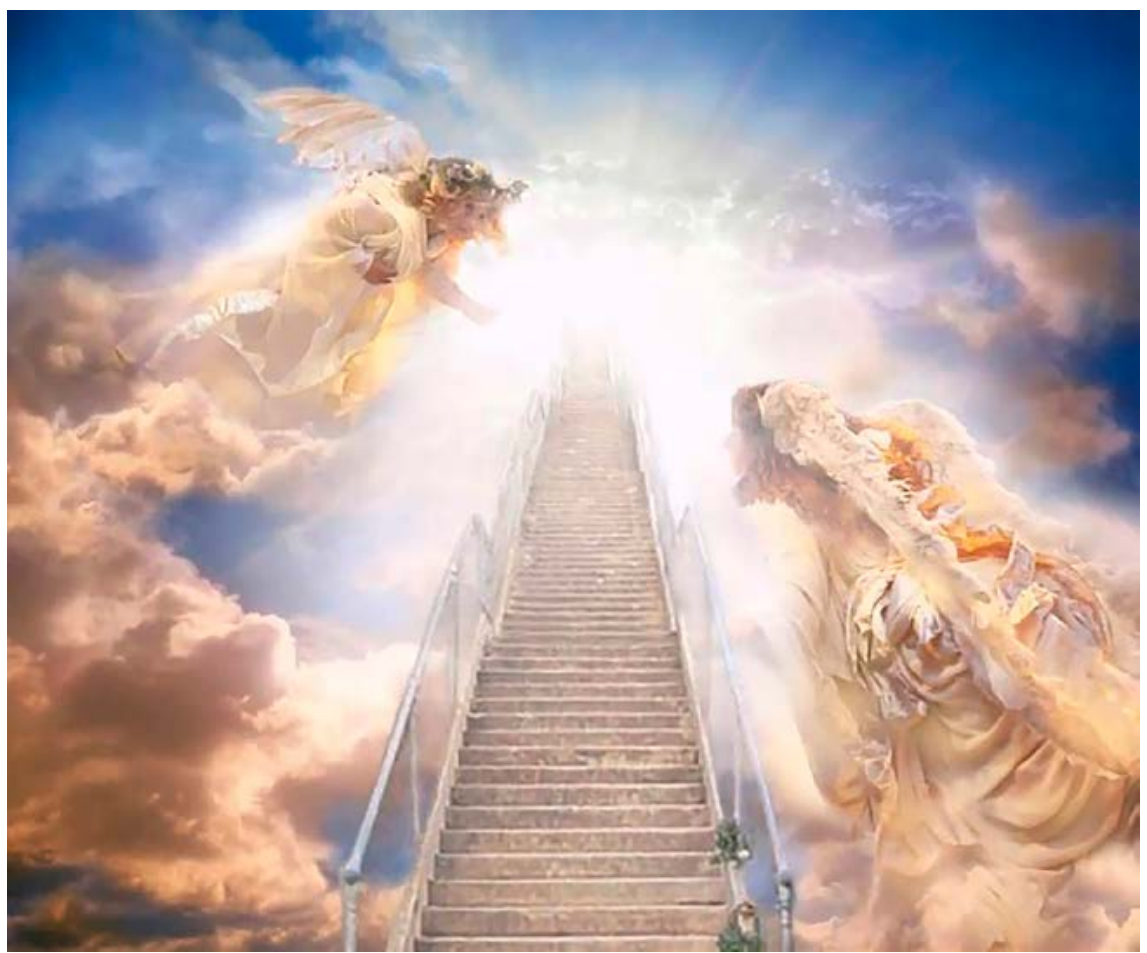

Figure 1. Angels guard the stairs that the dead climb into heaven (Gustavsson 2011: 190. https://www.mdpi.com/humanities/humanities-04-00224/article_deploy/html/images/ humanities-04-00224-g005.png).

\section{THE DECEASED AS ANGELIC BEINGS}

A common concept is that children and young people become angels after death. This is in striking contrast to earlier beliefs, in which the deceased were supposed to be souls, not angels. The British sociologist Tony Walter (2011) has also found a similar change in England. The mothers of dead children call themselves "mothers of angels." In addition, there is a glorification of the deceased by calling him or her the very best, finest, or prettiest angel in heaven. The deceased can continue to spread joy and humor in heaven just as he or she had done on Earth. The similarities between earthly life and an existence among the angels are obvious.

There are some examples of belief in the deceased already having been an angel while on Earth and having acted there as a loan to their relatives and friends. When Madeleine died in 2007 at age fifteen, one message read: "you have always been an angel and now you've got your glory." The folklorist Bente Gullveig Alver (1999a) has shown that earlier concepts of a guardian angel have been changed in modern religiosity to become the angelic wings that human beings themselves receive. The supernatural is relocated onto the individual from the outside and then accompanies him or her even after death into a new existence. 
One might expect that only the best individuals would be able to become angels. This is not the case, however. There are messages that speak of and regret the deceased person's drug addiction that brought him (they are generally young men) to an early death. A sister of Daniel, who died in 2007 at age thirty-three, wrote: "Drugs determined your fate, they took you from us. My beloved brother has become an angel, he has left us here below."

\section{CONCEPTS ABOUT STILLBORN INFANTS IN SWEDEN}

When a child dies in the womb, it is not unusual for a mother in Sweden, but infrequent in Norway, to write one or more messages on memorial websites. The declaration often expressed is that the stillborn infant was an angel. This angel was in a hurry to return to heaven, where the other angels dwell. The idea that the infant was a loan occasionally occurs. In such cases, God is sometimes named. Angels are most often mentioned, but without God being mentioned. Mothers may call themselves "angel mommies." A picture of a child with angel's wings may be included. This is especially noticeable in messages that are written on anniversaries of the delivery. Parents may then imagine a birthday party in heaven and even send up a balloon.

A final characteristic of the Swedish memorial websites for stillborn infants is that they really do not differ in any way from those websites relating to children that lived and later died. In their grief reactions, parents do not differ between a formerly living child and a stillborn one. They have been borrowed whether they were born alive or died in the womb. After their own deaths, parents anticipate meeting both stillborn infants and children that lived on Earth. A future reunion of this kind is depicted in positive phrases and will never end.

\section{BELIEF IN AN AFTERLIFE AFTER SUICIDE IN SWEDEN}

Some Swedish memorial websites show that close relatives find comfort in believing that a person that died by suicide can have a different existence after death. It is believed to be better than the life the deceased consciously chose to leave. However, this new existence is conceived as being diffuse. A message about Maja, who committed suicide in 2009 at age twenty-six, noted: "She chose to go on to a new life, where she is probably happier than here on Earth." No thoughts of punishment after death are expressed. This corresponds fully with the neo-religious concepts of "the regained paradise" (Alver, 1999b).

The surviving relatives are also believed to be able to make contact with the deceased person in his or her new existence. After Johan committed suicide in 2005 at age forty-four, a sister wrote: "I talk to you every day, hope you hear me, see me, and are with me. Love you forever."Numerous messages also mention the probability of a reunion between the surviving relatives and the deceased in some vague future. A sister of Pierre, who took his life in 


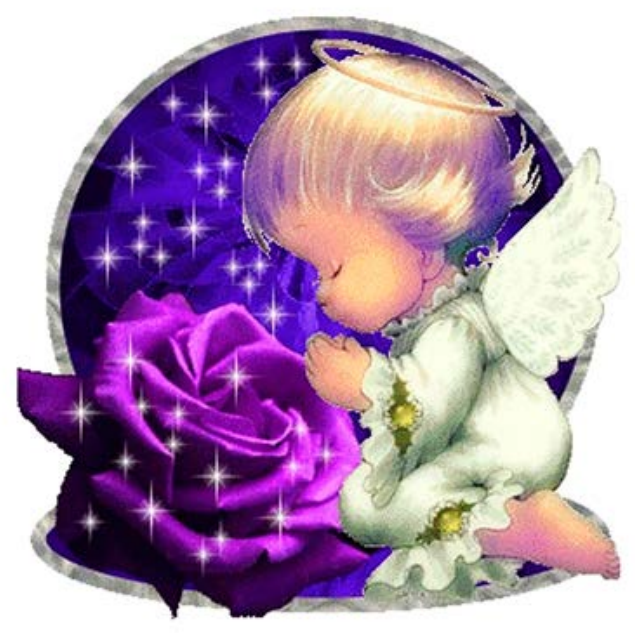

Figure 2. The mother of a deceased daughter wrote: "Hugs from your beloved mother." The angel has both a halo and wings, and may be thought to be the daughter (http://www.tillminneav.se/ showPage.php?id=34).
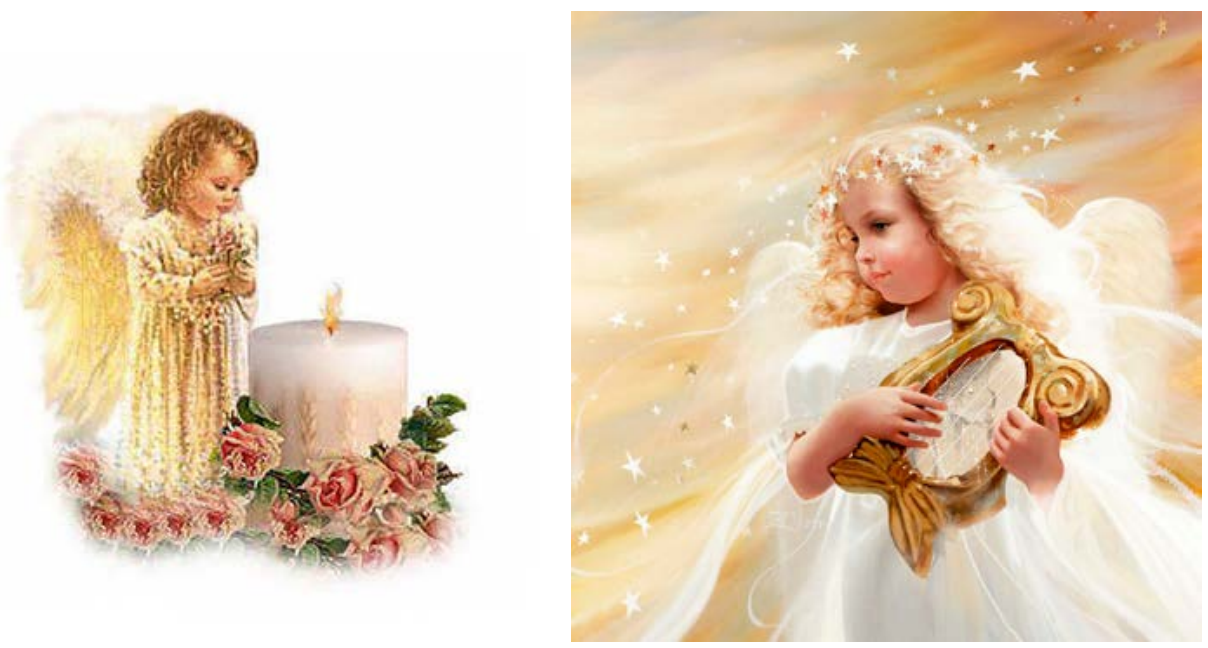

Figure 3. "Light a candle for my angel-child" (October 31, 2009); Figure 4. "Protective angel" (November 22, 2009), wrote Ehline’s mother (http://www.minneavehline.blogg.se). 
2005 at age twenty, wrote: "I hope you will meet all of us, one after the other, with wide-open arms when it's our turn to come to the other side because I know you are there somewhere and are waiting for us."

The deceased can also meet angels in the afterlife, who care for him or her. Sometimes a "city of angels" is mentioned. The deceased can also be conceived of as being an angel. A glorification of the deceased often occurs in which the latter is seen as being the best angel that can be found. After Robin took his life in 2008 at age twenty, his mother wrote to him: "Robin, now you're a real angel, the loveliest, most wonderful angel in the whole universe. Sleep well, my child, we'll meet again someday." Upon becoming an angel, the deceased is thought to be able to watch over and protect the surviving relatives on Earth.

In Norway one does not encounter concepts of an existence after death for those that have committed suicide. Angels are therefore not mentioned either. Glorification or expressions of honor are unthinkable because this could lead to others being tempted to new suicides. There is not only more reticence in Norway about speaking of suicide; there also appears to be more keeping to former negative beliefs about those that commit suicide with reference to a coming afterlife. In this respect, the contrast with Sweden is very obvious. The stability of tradition is clearly more evident in Norway.

A more obvious degree of secularization clearly plays a role in Sweden. Another factor is the individualism that in many ways has been shown to be more evident in Sweden than in Norway. In Sweden there is often a tendency to regard what is new as positive.

\section{FAITH ABOUT DECEASED PETS}

This study of the internet on attitudes toward deceased pet cats focuses on pet owners' expressions of their faith. Can concepts about an existence after death for animals also be perceived?

Swedish memorial websites for deceased pets began to appear at the turn of the millennium, in 2000. Their number has noticeably increased since 2005. During the 2000s they also began to appear in Norway, even if not to the same extent as in Sweden. A total of eleven such memorial websites are examined in this study.

One expression is that a deceased cat has passed over the "rainbow bridge" to another world, the "Rainbow Country," where there are only positive properties. This world is described in a poem by the author Paul C. Dahm and is cited in some of the internet contributions. The internet site www.regnbagsbron.org has the subtitle "Memorial site for beloved pets." In some cases a rainbow is depicted as well as a "rainbow bridge" that winds up toward the clouds. The assurance about a new existence in heaven can be clearly expressed without involving any form of doubt. Vendela wrote to her cat Tigger: "Some people say we don't go to heaven when we die, but you can be certain that you will. Because your heart is made of pure and solid gold." 


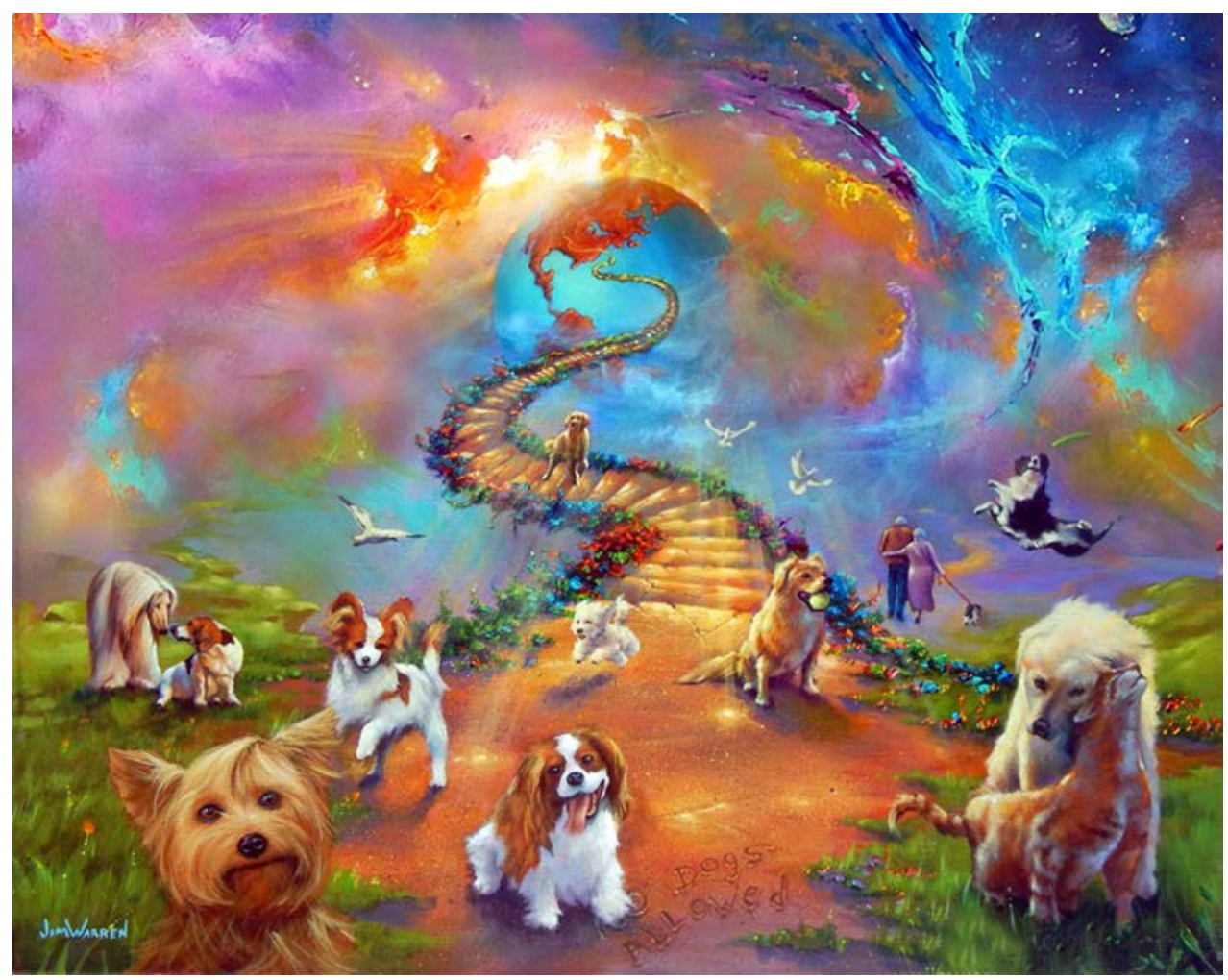

Figure 5. "All dogs go to Heaven." An image of the rainbow bridge that connects heaven with earth (CJimWarren, Jimwarren.com).

An expression that is often encountered concerns a feline heaven. There the deceased cat will also quickly meet other cats, among them those that have died earlier and that the cat knew during its earthly life. As the owner of the cat Lotus wrote: "Now you are together with seventeen-year-old Svante, running about in green fields and chasing butterflies." The cat is thus believed to have acquired a new life that has a strong resemblance to its former conditions of life on Earth. Earthly life is in this way projected onto an assumed existence after death like the situation for deceased humans.

A motif that often recurs in Swedish statements is the concept of a reunion or a meeting with the cat and its owners in a future transcendent existence. In other cases, a future meeting can be expressed as being very specific, like the words to the cat Emil (1996-2002): "Husse and matte [the owners] hope we will meet you again on the other side. We hope you will greet us at the door when it is our turn to go through the pearly gates."

After this kind of future meeting, no painful parting would ever occur. The following was written by its owner to Rasmus, a kitten a few months old: "I know we'll meet again after a very long time. . . Then we will always belong together. And, when that day comes, nothing will ever part us again." 
There are also some instances in Sweden, as well as a few in Norway, of a cat being ascribed an angelic character. This shows an obvious similarity to that which has become usual on memorial sites dedicated to humans. The cat Mitzi is characterized as being "an angel in cat heaven." Other angels in heaven can express joy because the dead cat now enjoys a new existence. The two Norwegian examples of the use of "angel" do not mention a possible future existence in Heaven. Such expressions of faith are reserved solely for deceased persons in Norway, in keeping with the older Christian tradition that has not felt the influence of religious modes of thought in recent years.

Evidence has also been found in Sweden, but not in Norway, that grief-stricken owners have conducted conversations with their dead cats on the internet in the hope that the cats will be able to hear the communications. The cat Isa, which died at age fifteen in 2001, received the following message from her owner: "I want you to know that I keep a picture of you on my bedside table and that I chat with you every evening and say good night, have you heard me?" An expressed Christian faith can be conveyed in some cases in Sweden. After the three-year-old cat Zhiney died in 2002, its owner prayed: "May God bless her. Heavenly Peace."

Norwegian internet sites also contain some examples concerning a fairly diffuse existence after death for deceased cats, but far from as many as in Sweden. In Sweden, no general inconsistency is felt between having a Christian faith and practicing such forms of anthropomorphism. That the spiritual dimension after death is much more pronounced in Sweden must be regarded as an expression of a more obvious secularization in Sweden than in Norway. A main result is that the previously strict boundaries between humans and pets have increasingly disappeared in Sweden, whereas they continue to exist in Norway. Norwegian contributions sometimes indicate a direct criticism toward "humanlike characterization."

\section{CONCLUDING REMARKS}

This study has shown that much information is available to scholars in cultural science about concepts of faith through a study of memorial websites for deceased persons and pets on the internet. The attention given to stillborn infants in Sweden is similar to that given to children that lived and then died. In Sweden, the differences between suicides and other deaths have been increasingly erased. Boundaries between humans and pets are also in the process of being obliterated on the memorial websites. This demonstrates an obvious difference compared to the previously maintained distinctions that held animals outside the spiritual and religious sphere. Equality, not differentiation, should apply to all, according to the dominant political and medial norms that have become increasingly strong in Sweden.

An examination of the messages' content often reveals a concept of some form of belief in a heavenly existence after death. This is seldom denied. Ideas about a supernatural 
existence vary on a scale ranging from the diffuse to the fairly concrete. In heaven, deceased individuals or pets can become acquainted with other deceased persons and animals even if they have not had previous social contact. Association and fellowship can then arise. The heavenly existence also includes angels that are thought to care well for the deceased. The deceased can also become angels. The concept of angels has replaced the earlier usual concept of souls. Existence among angels is entirely positive. Neither darkness nor punishment occurs after death. Opportunities for contact between the living and the dead can take place through the dead being believed to be able to read what is written on the memorial websites. The verb know, rather than believe, is used in such connections. The deceased can also contact the living by watching over them like guardian angels.

The living believe that their ultimate contact with the deceased will occur after their own death. Then the relationship will be everlasting. In Sweden this also regards deceased pets. Finiteness is replaced by the everlasting. This is something to look forward to, and this belief is often expressed on the websites.

In Norway, the boundary between suicide and other deaths is marked in an entirely different manner. Glorification or expressions of honor are unthinkable because this could lead to others being tempted to new suicides. In Norway there are no concepts of a bright afterlife or of angels in connection with suicides.

Older traditions have been shown to survive longer in present-day Norway than in Sweden. In Sweden there is a greater tendency to adopt innovations and set aside longstanding traditions. Memorial websites to the deceased generally contain far more traditional Christian concepts in Norway than in Sweden. This concerns, for example, references to God and Jesus. In Sweden one observes more of a diffuse, general religiosity that can remind one of New Age modes of thought, in which individuals and the brightness of a coming existence have a prominent position.

It can be difficult to give an explicit answer as to why former traditions associated with the deceased in general and to suicides and pets in particular have a stronger position in Norway. A more obvious degree of secularization clearly plays a role in Sweden. Another factor is the individualism that in many ways has been shown to be more evident in Sweden than in Norway. This is especially noticeable in the choice of symbols on gravestones in recent times (Gustavsson, 2011: 39). In Sweden there is often a tendency to regard what is new as positive, and to focus on the cheerful events emphasized by the media. The result can be that one covers over anything that is sorrowful. Life's darkest moments can be given a brighter shape. In this respect, Norway can be seen as being more realistic in its preservation of older traditions and in not merely rejecting life's darker sides without further discussion.

The internet contributions studied here provide opportunities for establishing a number of fundamental ideas about contemporary people. It is obvious that intense emotions need to find expression in words and not be suppressed within the systems and thoughts of the separate individuals. A process of grief must be allowed to be shared with others even if this is not done verbally within one's immediate circle of friends and relatives. It is not 
unproblematic to converse with just anyone at all about one's innermost feelings and traumatic experiences. Here the internet can serve as a public sphere providing welcome relief when struggling to endure the difficulties of a grief process. Mourners can sit at their PCs in the privacy of their homes and express their innermost feelings and beliefs, and they can communicate these to a large number of mostly unknown people.

\section{REFERENCES}

Alver, Bente Gullveig. 1999a. Fra englevagt til englevinger [From angel watch to angel wings]. In Myte, magi og mirakel i möte med det modern, eds. Bente Gullveig Alver et al., 183-199. Oslo: Pax.

Alver, Bente Gullveig. 1999b. Paradise Recaptured: Experience, Interpretation and Narrative. In Folk religion: Continuity and Change, eds. Anders Gustavsson and Maria Santa Montez, 325-334. Lisboa: Universidade Nova.

Gilhus, Ingvild Sælid, and Lisbeth Mikaelsson. 2005. Kulturens refortrylling: Nyreligiositet i moderne samfunn [The enchantment of culture: New religiosity in modern societies]. Oslo: Universitetsforlaget.

Gustavsson, Anders. 2011. Cultural Studies on Death and Dying in Scandinavia. Oslo: Novus.

Kraft, Siv Ellen. 2011. Hva er nyreligiøsitet [What is new religiosity?]. Oslo: Universitetsforlaget.

Krawczyk-Waasilewska, Violetta, Theo Meder, and Andy Ross, eds. 2012. Shaping Virtual Lives: Online Identities, Representations, and Conducts. Lódz: Lódz University Press.

Margry, Peter Jan, and Christina Sanchez-Carretero, eds. 2011. Grassroots Memorials: The Politics of Memorializing Traumatic Death. New York: Berghahn.

Walter, Tony. 2011. Angels not Souls: Popular Religion in the Online Mourning for British Celebrity Jade Goody. Religion 41 (1): 29-51. DOI: https://doi.org/10.1080/0048721X.2011.553138.

\section{VERA, SMRT IN SVETOVNI SPLET NA NORVEŠKEM IN ŠVEDSKEM}

Eno glavnih vprašanj pri raziskavah spominskih spletnih mest se nanaša na to, kako žalujoči izražajo čustva in katera prepričanja prevladujejo o posmrtnem življenju pokojne osebe. Pregled vsebine sporočil največkrat razkrije koncept določene oblike vere v nebesa in v življenje po smrti; le redko je opazno zanikanje. Ideje o nadnaravnem obstoju so zelo različne, od razpršenih do precej konkretnih zamisli. Na splošno pa angeli obstajajo, po smrti se ne zgodi niti tema niti kazen, živi pa verjamejo, da se bodo po svoji smrti srečali spokojnikom in z njim večno živeli.

Na Švedskem velja to tudi za pokojne hišne ljubljenčke. Prej še stroge meje med posmrtnim življenjem ljudi in hišnih ljubljenčkov na Švedskem vse bolj izginjajo, norveški prispevki pa občasno kažejo na neposredno kritiko "človeške karakterizacije "domačih živali. Pokazalo se je, da danes na Norveškem starejše tradicije preživijo dlje kakor na Švedskem, kjer je bolj navzoča težnja po sprejemanju inovacij in po odmiku od dolgoletnih tradicij. To je mogoče razbrati tudi na spominskih spletnih mestih, kjer je na Norveškem opazno veliko več tradicionalnih krščanskih 
ANDERS GUSTAVSSON

konceptov kakor na Švedskem. Na Švedskem gre za bolj razpršeno, splošno religioznost, ki labko spominja na novodobne načine mišljenja, v katerih je v ospredju individualizem, kar kaže na višjo stopnjo sekularizacije.

Dr. Anders Gustavsson, University of Oslo, anders.gustavsson@ikos.uio.no 